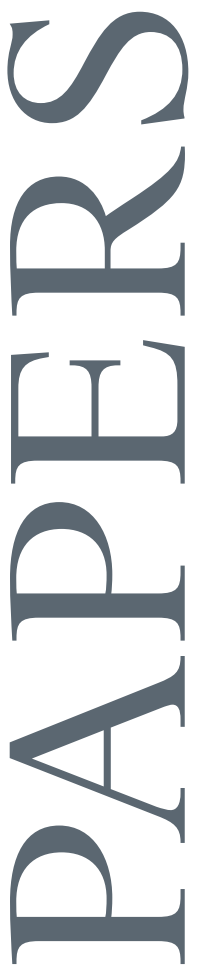

EAST-WEST CENTER WORKING PAPERS

\author{
Economics Series
}

No. 130, June 2012

\title{
The Microeconomics of North-South Korean Cross-Border Integration
}

Stephan Haggard and Marcus Noland

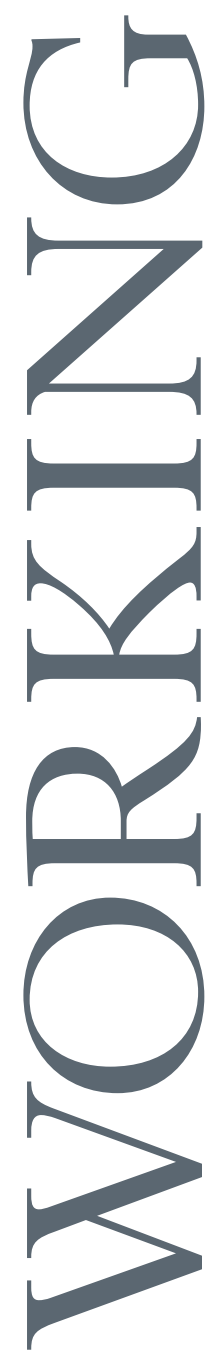

Je $\frac{\text { E A S T - W E S T C E N T E R }}{\text { COLlaboration • EXPertise - LeAdership }}$ 


\title{
The Microeconomics of North-South Korean Cross-Border Integration
}

\author{
Stephan Haggard and Marcus Noland
}

East-West Center Working Papers is an unreviewed and unedited prepublication series reporting on research in progress. The views expressed are those of the author and not necessarily those of the Center. East-West Center Working Papers are circulated for comment and to inform interested colleagues about work in progress at the Center.

Working Papers are available online for free at EastWestCenter.org/ewcworkingpapers. To order print copies ( $\$ 3.00$ each plus shipping and handling), contact the Center's Publication Sales Office.

The East-West Center promotes better relations and understanding among the people and nations of the United States, Asia, and the Pacific through cooperative study, research, and dialogue. Established by the US Congress in 1960, the Center serves as a resource for information and analysis on critical issues of common concern, bringing people together to exchange views, build expertise, and develop policy options.

The Center's 21-acre Honolulu campus, adjacent to the University of Hawai'i at Mānoa, is located midway between Asia and the US mainland and features research, residential, and international conference facilities. The Center's Washington, DC, office focuses on preparing the United States for an era of growing Asia Pacific prominence.

The Center is an independent, public, nonprofit organization with funding from the US government, and additional support provided by private agencies, individuals, foundations, corporations, and governments in the region.

\section{EastWestCenter.org/publications}

Publication Sales Office| East-West Center 1601 East-West Road | Honolulu, Hawai'i 96848-1601

Tel: 808.944.7145 | Fax: 808.944.7376

EWCBooks@EastWestCenter.org
Stephan Haggard is the Lawrence and Sallye Krause Professor at the University of California, San Diego Graduate School of International Relations and Pacific Studies. He is the author of The Political Economy of the Asian Financial Crisis (2000), and coauthor of The Political Economy of Democratic Transitions (1995), Famine in North Korea: Markets, Aid, and Reform, Witness to Transformation: Refugee Insights into North Korea (2011), and Engaging North Korea: the Role of Economic Statecraft (2011).

Marcus Noland is a non-resident senior fellow in the Research Program of the East-West Center and the deputy director of the Peterson Institute for International Economics. He was a senior economist at the Council of Economic Advisers in the Executive Office of the President of the United States and has held research or teaching positions at Yale University, the Johns Hopkins University, the University of Southern California, Tokyo University, Saitama University (now the National Graduate Institute for Policy Studies), the University of Ghana, and the Korea Development Institute. Noland is the author of Korea after Kim Jong-il (2004) and Avoiding the Apocalypse: The Future of the Two Koreas (2000), which won the 2000-2001 Ohira Memorial Award, and coauthor of Famine in North Korea: Markets, Aid, and Reform, Witness to Transformation: Refugee Insights into North Korea (2011), and Engaging North Korea: the Role of Economic Statecraft (2011).

The authors would like to thank Alex Melton for able research assistance. This work was supported by the Smith Richardson Foundation and Academy of Korean Studies grant AKS-2011-R39. 


\title{
The Microeconomics of North-South Korean Cross-Border Integration
}

\author{
Stephan Haggard and Marcus Noland
}

\begin{abstract}
Economic integration between North and South Korea occurs through three modalities: traditional arm's-length trade and investment, processing on commission (POC) trade, and operations within the Kaesong Industrial Complex (KIC). In order, these three modalities are characterized by decreasing exposure of South Korean firms to North Korean policy and infrastructure. Through a survey of 200 South Korean firms operating in North Korea we find that these modalities of exchange matter greatly in terms of implied risk. For example, firms operating in the KIC are able to transact on significantly looser financial terms than those outside it. We find that direct and indirect South Korean public policy interventions influence these different modalities of exchange and thus impact entry, profitability, and sustainability of South Korean business activities in the North. In effect, the South Korean government has substituted relatively strong South Korean institutions for the relatively weak Northern ones in the KIC, thus socializing risk. As a result, the level and type of cross-border integration observed in the survey is very much a product of South Korean public policy.
\end{abstract}

JEL Codes: P3, F15, P33

Keywords: economic integration, transition, institutions, socialization of risk, South Korea, North Korea

Stephan Haggard is the Lawrence and Sallye Krause Professor at the University of California, San Diego Graduate School of International Relations and Pacific Studies. He is the author of The Political Economy of the Asian Financial Crisis (2000), and coauthor of The Political Economy of Democratic Transitions (1995), Famine in North Korea: Markets, Aid, and Reform, Witness to Transformation: Refugee Insights into North Korea (2011) and Engaging North Korea: the Role of Economic Statecraft (2011). Marcus Noland is a non-resident senior fellow at the East-West Center and the deputy director of the Peterson Institute for International Economics. He was a senior economist at the Council of Economic Advisers in the Executive Office of the President of the United States and has held research or teaching positions at Yale University, the Johns Hopkins University, the University of Southern California, Tokyo University, Saitama University (now the National Graduate Institute for Policy Studies), the University of Ghana, the Korea Development Institute, and the East-West Center. Noland is the author of Korea after Kim Jong-il (2004) and Avoiding the Apocalypse: The Future of the Two Koreas (2000), which won the 2000-2001 Ohira Memorial Award, and coauthor of Famine in North Korea: Markets, Aid, and Reform, Witness to Transformation: Refugee Insights into North Korea (2011), and Engaging North Korea: the Role of Economic Statecraft (2011).

Note: We would like to thank Alex Melton for able research assistance. This work was supported by the Smith Richardson Foundation and Academy of Korean Studies grant AKS-2011-R39. 
It is well-established that institutional quality has a significant impact on cross-border trade and investment and economic development more broadly (Wei 2000, Anderson and Marcoullier 2002, Moenius and Berkowitz 2011). North Korea's institutional environment is extraordinarily weak, and could be expected to affect both the magnitude and nature of cross-border exchange.

Following the partition of the peninsula, there were virtually no cross-border trade and investment relations between North and South Korea. When cross-border integration began in the 1990s, the majority of trade took the form of processing on commission (POC) relations. Under this arrangement, South Korea firms shipped inputs to North Korea for assembly by North Korean partners with the finished products re-exported for sale in South Korea or other third country markets. A typical example would involve South Korean garment manufacturers transshipping cut cloth, buttons, and thread through China to North Korea where the components would be sewn into shirts and then re-exported back through China for sale outside North Korea. The remainder took the form of traditional arm's-length transactions between unrelated parties.

A third modality of exchange subsequently developed at the Kaesong Industrial Complex (KIC). The zone, which opened in December 2004, sits just north of the North-South border and is easily accessible from Seoul. Firms in KIC are engaged in processing and assembly activities. Inputs are sourced in South Korea, transported to KIC, fabricated into finished products by North Korean workers hired via a state labor exchange, and then transported back to South Korea for sale in the South Korean or third country markets.

These three modalities of exchange rest on very different institutional foundations, and thus allow us to identify the implicit costs of North Korea's institutional weakness. Conventional or so-called general trade and investment involves the greatest direct contact with North Korean counterparties, policies, and institutions. POC trade involves activity undertaken with North Korean partners whose primary function is to supply labor, though they may also supply land, plant, and equipment. Because POC exports from the North are dedicated to particular clients, we can think of these arrangements as involving some degree of explicit or implicit joint management by South and North Korean entities.

KIC assembly activities, by contrast, are conducted by a South Korean subsidiary using North Korean labor in an export-processing zone in which the South Korean government and firms have played a considerable role in the supply of both physical infrastructure and management. While it would be an exaggeration to say that KIC is a bit of South Korea located 
within North Korea, the degree of South Korean official involvement in both the provision of its physical infrastructure and the management of the zone make operations there notably distinct from the arm's-length trade or POC activities outside the zone, which are far more exposed to North Korea's dilapidated infrastructure and the vagaries of the regime's capricious regulation. For importers and investors involved in resource extraction activities such as mining, niche agriculture, or marine products, "general" trade is really the only viable alternative. Firms involved in manufacturing have a greater range of choices, encompassing all three modalities.

Drawing on a formal survey of 250 South Korean firms-200 doing business in North Korea and 50 which never entered - in the context of North Korea's weak institutional environment, we find that South Korean public policy has a substantial impact on the level and composition of cross-border integration, affecting entry, the modality of operations, and their sustainability. State support is a significant factor in entry; among other determinants, firms receiving government support are more likely to enter. Moreover, such support is associated with establishment of operations at the relatively less risky KIC. Also telling is the dog that did not bark: indicators of informal institutions of contract enforcement and dispute settlement such as introduction networks, the duration of a firm's relationship with its counterparty, and briberyall of which play a significant part in China-North Korea business - are less important in this setting. Rather, direct and indirect South Korean public policy interventions appear to be what matter.

The impact of North Korea's relatively weak institutional environment extends to the financial terms on which these cross-border exchanges occur. Virtually none of the firms extend credit to their counterparties. Settlement terms implicitly constitute a form of financing, and provide implicit evidence on risk. The nature of the implicit risk premium can be seen in the fact that stricter financing terms are imposed on North Korean counterparties while firms operating in the KIC transact at significantly looser financial terms than those operating elsewhere, even controlling for the much lower incidence of North Korean counterparties.

In sum, North Korea is a risky place and direct and indirect South Korean public policy interventions effectively socialize risk, substituting relatively strong South Korean institutions for relatively weak institutions in the North. Two findings follow. First, the level and type of cross-border integration observed in the survey is very much a product of South Korean public 
policy. Second, North Korea effectively foregoes substantial economic integration because of the failure of institutions outside of the KIC to similarly mitigate risk.

\section{Who Are the Participants?}

The results reported here are derived from a survey of 250 firms conducted between November 2009 and March 2010, 200 of which had been engaged in trade or investment and a matched control group of 50 firms that were not doing business with the North. Of the 200 firms that were or had done business in the North, 181 were active in North Korea at the time the survey was conducted, while 18 others ("the quitters") had exited at the time of the survey. ${ }^{1}$ As there are no public business registries listing firms engaged in business with North Korea, the firms necessarily constitute a sample of convenience, culled from a variety of sources. However, extensive interviews suggest that the sample is broadly representative of the cross-border business. At its peak in the late 2000s, roughly 400 South Korean firms were engaged in economic activities in the North outside of KIC, meaning that our sample constituted a significant share of the universe. We are also able to draw some conclusions about the nature of the cross-border exchange though comparison with a control group of 50 South Korean firms that were not doing business in North Korea at the time of the survey. See the appendix for methodological detail.

Most of these firms are small (less than 10 employees), and relatively young (established within ten years of the survey), though there were a handful of large firms (more than 1000 employees) and established firms (more than 50 years old) firms in the survey. A slight majority (53 percent) were headquartered in Seoul, though all South Korean provinces except Jeju Island are represented.

The firms include listed public companies, private enterprises, and individual proprietorships. Most reported access to outside finance via commercial banks (58 percent), but 7 percent identified public sector financial institutions as their primary source of funding.

${ }^{1}$ One respondent was found to be doing business exclusively with other South Korean firms at KIC and was subsequently excluded from the analysis, leaving an effective sample of 199 firms. 
The South Korean firms doing business in North Korea are engaged in importing, exporting, and investment through either arm's-length transactions, POC trade, or the KIC; the permutations and combinations of these three activities are diagrammed in figure 1. Nearly all of the firms in the sample (94 percent) were involved in importing, either directly from North Korean counterparties (59 percent) or via some kind of processing relationship (33 percent). By contrast, less than half the sample - 45 percent-were involved in exporting either directly to North Korean counterparties (12 percent) or more frequently in the context of processing relationships (33 percent).

Thirty-two firms, or 16 percent of the sample, had invested in North Korea. Of these investors, most reported stand-alone investments without North Korean partners ( 72 percent). When asked about their motivation for investment, most established operations primarily aimed at selling to the South Korean market; the remaining responses were equally divided among selling to the North Korean market, exporting to third country markets, or exploiting natural resources.

A plurality of the firms doing business in North Korea were engaged directly in manufacturing ( 47 percent), followed by trade (33 percent), agriculture, forest, and fisheries (13 percent), construction ( 4 percent), services ( 3 percent), and mining ( 1 percent). Not surprisingly POC firms are more concentrated in manufacturing (89 percent), and the KIC firms were engaged exclusively in this sector. This pattern contrasts with the results of a survey of 300 Chinese enterprises operating in North Korea by Haggard, Lee, and Noland (2012) (hereafter "the China survey") where pure trading activities were more prevalent.

On the export side, trade is concentrated in textiles and clothing, particularly among firms engaged in processing activities, including at KIC (table 1). On the import side, food and fisheries products are most important, followed by textiles and apparel; this latter category of imports reflecting the return-side of POC relationships, as well as assembly activities at KIC. However, among arm's-length exporters, industrial equipment and intermediates are more prominent.

The earliest any respondent indicated entering the North Korean market was 1986, but the cases entering before the political breakthrough of the 2000 summit are relatively limited. 
The majority of firms entered since 2004, which corresponds to the initiation of activities at KIC (figure 2). ${ }^{2}$

In North Korea, the primary location of activity for a plurality of the respondents was Pyongyang (29 percent), followed by KIC (26 percent), and North Hamgyung (20 percent), with other locations less frequently cited.

In comparison to the firms having done business in North Korea, the control group of firms having never done business in North Korea is slightly older and slightly larger, and more concentrated in manufacturing. Most control group respondents reported never having considered entering the North Korean market, mostly out of lack of familiarity.

We obviously have less information on the primary counterparties of the firms having done business in North Korea. More than 80 percent of the respondents report involvement with only a single North Korean counterparty. Moreover, nearly half of both exporters and importers report that a majority of their revenues are accounted for by transactions with North Korea (figure 3); this subsample of firms is largely dedicated to doing business with North Korea. This dependence on the North Korea trade appears to be particularly acute for firms engaged in processing activities.

One of the critical differences between the results obtained from this survey and an earlier survey of Chinese enterprises reported in Haggard, Lee, and Noland (2012) and Haggard and Noland (2012) is the much more prominent role of non-North Korean counterparties (figure 4). Pure importers and exporters report that a majority of their counterparties are North Korean entities, mostly state-owned enterprises (SOEs), followed by governmental units. ${ }^{3}$ The other

${ }^{2}$ A similar pattern of responses was obtained to a question asking when the respondent established a relationship with their most significant counterparty - most of these relationships were established after 2004.

${ }^{3}$ The SOE category itself is a bit problematic, encompassing entities and economic behaviors of at least three different types. The first are SOEs engaged in their traditional, legally sanctioned lines of business, presumably subject to extensive direct political control. The second are SOE's whose managers have exploited the company's legal status and resources to initiate non-traditional and in some cases completely unrelated (and even illicit) lines of business. Third, entrepreneurs affiliate with SOE's for political protection (Kim 2007); the SOE may in fact be a shell for an effective joint venture partnership. Similar uncertainty about the true nature of the enterprise exists for other types of counterparties that are reported in the survey such as North Korean government offices. Thus while the plurality of counterparties are identified as SOEs, de 
modalities report a more diverse set of counterparties but firms operating in KIC appear particularly distinct. These firms not only operate in a distinctive institutional enclave, but they also with much less involvement with North Korean SOEs; rather, they do business to a much greater extent with South Korean or third party firms, a factor which no doubt also influences the risk environment.

The South Korean firms were asked about how they learned about their main business partner ("Before your company established official business relationship with this client, through which channels did your company learn about this client?") These results are reported in table 2. What is striking is the relative absence of North Korean public and private connections in encouraging business. This pattern may be explainable in part by the tight political controls exercised by both the North and South Korean governments over North-South contacts. But it also reflects the broader phenomenon noted here: that North-South trade has been driven in no small measure by South Korean political efforts to promote engagement. South Korean public and private connections are the primary introductory channels in all cases, with the public role focused largely on the KIC, visible in the substantial role government introductions play in firms that do not have North Korean counterparties. ${ }^{4}$

Except with respect to firms operating in the KIC where Chinese influence is completely absent, Chinese channels are the next most important, particularly with respect to North Korean counterparties. This outcome reflects politics; the North and South Korean governments have more relaxed attitudes involving contacts between their respective nationals and Chinese than they do toward each other, encouraging the relatively less politically constrained Chinese entities to play an introductory role, particularly with respect to POC activities.

facto privatization of exchange may be occurring under the mantle of the state, including through corruption, and it is possible that even the South Korean firms themselves do not know the true story behind their counterparts.

${ }^{4}$ These private connections do not appear to be systematic or reflect the activities of formal private associations. When asked if they were aware of non-official organizations such as commercial associations that might be helpful in doing business in North Korea, only 13 percent indicated awareness of such organizations, and only a 16 percent of those (i.e., 2 percent of the whole sample of firms doing business in North Korea) had joined such an organization. 


\section{Subjective Assessments of the North Korean Business Environment}

Although selection effects are clearly operating, most South Korean firms operating in North Korea indicate that they are able to make a profit (figure 5) ${ }^{5}$ Nearly 80 percent, however, complain about North Korean infrastructure. Nearly two-thirds believe that it is risky to invest in North Korea because officials will change the rules ex post and/or that their investment will be expropriated. More than 60 percent complained about the ban on cell phones. ${ }^{6}$ A majority believe that a reduction in North Korean trade barriers had helped their business.

Apparent surprises emerge, however, when the responses are disaggregated between those inside and outside the KIC (figure 6). Relative to firms operating outside the zone, KIC firms had more negative appraisals of the regulatory environment, risks created by capricious regulation, and the possibility of expropriation. Why would firms in the $\mathrm{KIC}$ - at least partly sheltered from North Korean institutions_- have a more negative view of them? Although to be clear, these responses are informed by experience and not ex ante expectations prior to entry. One possible interpretation is that the KIC firms chose to use this modality precisely because they had relatively negative appraisals of conditions outside the zone. Relative to firms outside the zone, they quite naturally did not regard the quality of infrastructure as much of an issue. But even on this question, 70 percent indicated that they viewed it as a problem; again, this could be interpreted as a motivation to avoid North Korean risk by entering the market via the KIC.

Is the reported profitability of most South Korean firms operating in North Korea an artifact of government support for trade and investment with the North Korea? Overall, 70 percent of the firms report receiving no direct support (table 3), though the existence of KIC itself could be considered a form of indirect support. Among those who did report assistance, it took the form of trade preferences (23 percent), special financing ( 8 percent), export-import insurance ( 4 percent), and investment guarantees ( 3 percent). But when the responses are

\footnotetext{
${ }^{5}$ The exception is the quitters, only one-third of which reported making a profit. Their responses to the other questions are similar to, if not somewhat more negative than, the overall group of respondents operating outside KIC.

${ }^{6}$ These were precisely the same four issues singled out by Chinese enterprises in an earlier survey (Haggard, Lee, and Noland 2012).
} 
disaggregated two results emerge. First, the financial support tools are directed largely at firms operating at KIC, a majority of which report receiving some kind of policy support. Second, policy support (or lack thereof) is one dimension where the currently active firms and the quitters look quite distinct. Among the quitters who reported noticeably lower likelihood of making a profit in comparison to the currently active firms, only 6 percent received trade preferences, and none received financial support. While one cannot say whether policy support is decisive in sustaining these operations, the correlation between support and those who have maintained operations is noticeable. Only a handful of firms reported receiving support from the North Korean government, and this was mainly in the form of trade preferences.

The survey of Chinese enterprises operating in North Korea as well as surveys of refugees document an economy in which bribery and corruption are commonplace (Kim 2010; Haggard and Noland 2012; Haggard, Lee, and Noland 2012). However when asked about irregular payments, a majority of the South Korean respondents strongly disagreed with the claim, a view that was shared widely across firms engaged in arm's-length transactions, POC trade, and KIC activities. Not surprisingly, investors, who are more exposed to regulatory and direct expropriation risk, have slightly less sanguine views on this topic, but even this group regards the phenomenon as much less of an issue than either the Chinese enterprises or the North Korea refugees previously surveyed. This apparent lack of vulnerability could possibly be related to a combination of better language and cultural skills that would allow them to fend off predation more effectively than their Chinese counterparts, and greater negotiating leverage visà-vis North Korean authorities than the typical individual citizen.

\section{Dispute Settlement}

A critical feature of the institutional environment of a market economy is the capacity of investors and traders to resolve disputes. Formal institutions of dispute settlement, typically courts or other means of formal arbitration, are often seen as the very cornerstone of a marketsupporting institutional environment even if those formal institutions are supplemented with informal ones. In previous research, courts have been found to improve the functioning of relational contracts and contribute to expanded trade and investment. Indeed, such institutions appear to be most important at the start of a trading relationship (Johnson, McMillan, and 
Woodruff 1999, 2002). The survey of Chinese enterprises found that disputes with their North Korean counterparts were fairly common.

In contrast, the South Korean firms reported relatively few disputes. The survey permitted respondents engaged in multiple types of business to characterize each of their principal business relationships separately, for example, allowing a single firm to report on relations with its main import, export, and investment partner. Overall, 6 percent of investors, 7 percent of exporters, and 11 percent of importers reported disputes with their primary counterparties. For the importers, the most frequently cited reason for a dispute was defective goods (43 percent), followed by declining quality (33 percent), and late shipments (14 percent).

However, this relatively sanguine picture changes if the respondents are disaggregated by modality and counterparty. So, for example, 25 percent of exporters and 20 percent of importers doing arm's-length transactions with North Korean counterparties reported disputes, comparable to the figures obtained in the China survey. Disputes were less frequent for firms involved in POC and KIC activities, or for those transacting with non-North Korean counterparties. ${ }^{7}$ For example, the rates at which disputes were reported for non-North Korean counterparties were 14 percent of arm's-length exporters, and 5 percent for arm's-length importers.

Of those firms which had experienced disputes, only a minority reported satisfaction with the resolution. Among importers for example, 57 percent reported that they were "not satisfied at all" with the resolution of the dispute, 33 percent were "not satisfied," and only 10 percent were "basically satisfied." Interestingly, while the incidence of disputes was lower for POC and KIC firms than for firms engaged in arm's-length transactions, they reported no higher rate of satisfaction in resolving the disputes that they had encountered.

Overall, disputes were relatively infrequent, so when asked the hypothetical "how would they resolve a dispute," 28 percent of firms engaged in exporting, 41 percent of firms engaged in importing, and 94 percent of firms engaged in investing (many of which are greenfield investments, including in KIC) did not respond. Among those which did provide valid responses, the pattern was similar across exporters and importers. Seventy-one percent indicated that they

${ }^{7}$ One possible reason for the lower dispute rates for KIC firms is the frequency of contact with their counterparty. Nearly all the KIC firms indicated that they communicated with their primary counterparty on a daily basis; for a handful of the non-KIC firms communication was as infrequent as once a year. 
would either settle matters privately or did not have recourse to any third-party intervention. Eighteen percent said that they would seek South Korean government intervention, while 10 percent said that they would seek the assistance of other South Korean firms. ${ }^{8}$ Five percent said that they would involve the North Korean central government, a single importer indicated that it would approach a local North Korean government, and no firm responded that it would attempt to settle matters in a North Korean court. Clearly, South Korean firms believe they are operating in an environment in which dispute settlement mechanisms are sorely lacking.

Among the subsample of firms that had experienced disputes, the results were equally striking. Nearly all indicated that they would either settle matters privately or had no access to third-party intervention. In the China survey, firms expressed a much greater willingness to use contacts in North Korean local and provincial governments to resolve disputes, and indeed, indicated that disputes were less likely to be resolved successfully as they were escalated from local to provincial to central government connections. By contrast, the only third-party dispute settlement mechanism that received any support in the South Korean sample was appeal to the North Korean central government (7 percent). South Korean firms may be under much closer political scrutiny by the North Korean authorities than their Chinese counterparts, and as a consequence less able than Chinese enterprises to work out disputes at lower political levels. Additionally, most of the South Korean firms, even ones in the KIC, report that they are required to get permission or approval from some level of the North Korean government (generally the central government) to do business in North Korea. This prior contact with the central government in the approval process may also help explain the tendency of South Korean firms to seek out support from central rather than local or provincial authorities in resolving disputes.

\section{Entry and Modality}

We use the control group of 50 firms not doing business in North Korea to establish what distinguishes firms that enter the market from those that do not. Among those that enter, we can also consider what determines those that subsequently leave. We then turn to the question of

\footnotetext{
${ }^{8}$ Recall that organized private networks did not appear to play much of a role in encouraging firms to begin business in North Korea.
} 
what drives choices regarding different modalities of activities: which firms choose to conduct arm's-length transactions, engage in POC trade, or locate in the KIC.

As indicated in the previous discussion, the survey yielded considerable information on the respondent firms. Among the variables that appeared uncorrelated with the decision to enter the North Korean market or were correlated but not robustly so in a multivariate context were legal status of the firm (listed, unlisted, sole proprietorship, foreign); sources of private funding; major product revenue share; location of headquarters other than Seoul; and the ability of the CEO to speak languages other than Korean and Chinese. Probit regressions estimated on entry are summarized in table 4. Included regressors are firm age, firm size, a headquarters in Seoul, the CEO's ability to speak Chinese, access to funding from state-affiliated sources, and involvement in manufacturing or trade. The central finding is that status as a small- or mediumsized enterprise (SME), access to state funding, and a headquarters located in Seoul are all positively related to entry. More weakly, firms listing trade as their primary activity are also more likely to enter. The CEO's ability to speak Chinese was also significant, in part because most of the POC trade runs through China and, as shown in table 2, Chinese networks play some introductory role. By contrast, manufacturing as a principal activity, and more weakly, firm age, are negatively associated with entry. In sum, the correlates suggest a rent-seeking or industrial policy model in which young SMEs in the capital Seoul, and particularly trading companies as distinct from manufacturers, receive state support to enter the market.

Conditional on entry, what form does that activity take: arm's-length trade and investment, POC trade, or production in the KIC? Table 5 reports polychotomous probit regressions on ordered categorical data where the arm's-length modality was coded 1, POC coded 2, and KIC coded 3. As we argued, these distinctions map to decreasing exposure to North Korean policy and infrastructure. The initial analysis of simple correlations between firm characteristics and modality of operations yielded a similar set of outcomes as in the entry case. In addition, variables on introduction networks, dispute settlement, and bribery were either uncorrelated or non-robustly correlated with modality choice.

The availability of commercial bank finance, finance via state-affiliated institutions, and access to special financing opportunities, all are associated with a reduced likelihood of choosing arm's-length transacting and toward a greater likelihood of locating in KIC. However, it is unclear whether this is a matter of these financing opportunities pushing firms away from arm's- 
length transacting and toward KIC, or whether the business activity less exposed to North Korean policy (and infrastructure) attracts financing. Conversely, principal involvement in nonmanufacturing reduced the likelihood of locating in KIC, as did having at least one North Korean counterparty. Initial specification searches suggested that having a Chinese speaking CEO might impact the modality choice as it did in regard to entry, but this variable is insignificant in specification 5.1 .

Finally, 18 firms in the sample reported having done business in North Korea, then subsequently exiting from the market. Probit results on this exit decision are reported in table 6. Unsurprisingly, the self-reported ability to make a profit is negatively correlated with exit (i.e.,

profitable firms stay in), as is the CEO's ability to speak Chinese. The absence of South Korean government support is positively correlated with exit. That is firms that did not receive government support were more likely to quit. Initial specification searches suggested that firm size might have something to do with the decision to exit, but these variables did not prove to be robust.

In sum, South Korean policy appears to play an important role in entry, exit, and the form that business takes. Funding from state-affiliated sources is associated with entry, and a lack of government support is associated with exit. Funding from state-affiliated sources and access to special financing programs are correlated with modality choice, though the direction of causality cannot be determined: whether the existence of funding opportunities have encouraged specific choices, or whether state funding has gravitated toward firms that have chosen forms of engagement that involve less exposure to North Korean policy and infrastructure. This observation leads quite naturally to a consideration of the nature of risk.

\section{Hierarchy of Risk}

In previous research on transitional economies in Europe and Asia, the extension of credit and financial settlement terms more broadly provide insight into the credibility of the operating environment and are frequently used as implicit indicators of risk and the existence or absence of trust in previous research (Johnson, McMillan, and Woodruff 1999, 2002; McMillan and Woodruff 1999a, 1999b). In the case of North-South economic integration, we can use the three different modalities of economic engagement, together with differential ability to use North and 
South Korean contract enforcement and dispute settlement depending on counterparty, to examine the influence of institutions on trade, recognizing that these outcomes may also reflect direct policy interventions by South Korea. Does operating in a more institutionalized environment - the $\mathrm{KIC}$ - give rise to different patterns of economic exchange than operating in North Korea proper?

The survey reveals an almost complete absence of lending between counterparties: Only a single South Korean importer out of 136 reported extending loans to its North Korean counterparty. ${ }^{9}$ However, relaxed settlement terms can be interpreted as an indirect form of financial support. While the overall numbers suggest that counterparties are permitted lax payment terms, it is clear that North Korean counterparties-as distinct from South Korean or third-country counterparties — are discriminated against in this regard (tables 7 and 8).

Moreover the provision of loose settlement terms is greatest with KIC, next for POC firms, and the least for arm's-length transactions. So, for example, two-thirds of pure exporters demand payment from their North Korean customers when the order is placed or at time of delivery. At the other extreme, none of the South Korean firms reporting imports via KIC paid less than 30 days after delivery. This pattern could arise from pure risk considerations arising, for example, from the dilapidated state of the North Korean infrastructure, and the difficulties this could create for counterparties outside the KIC to fulfill their obligations. It could also reflect legal or institutional differences across the three modalities, such as differences in contact enforceability

None of the firms report doing any business in either the North or South Korean won. Most transactions are done in US dollars, with barter and the euro distant second and third respectively. While this outcome of avoiding both the North and South Korean won might reflect politics, this pattern of little explicit credit, tight settlement terms, and avoidance of the North Korean won as settlement currency is consistent with the results obtained in the earlier China

${ }^{9}$ Two other firms reported extending loans to their South Korean counterparties. These results parallel those obtained in the China survey where less than 5 percent of the firms reported extending credit to their partners, with most of these cases (60 percent) involving Chinese SOEs extending loans to their North Korean SOE counterparties at a rate enormously disproportionate to this dyad's occurrence in the sample (5 percent). 
survey, where such North-South issues would not apply, and suggests that economics, and not just diplomacy, may be driving these outcomes.

Polychotomous probit regressions on ordered categorical data were initially estimated on import and export transactions separately with payment at the time the order was placed coded 1, payment at time of delivery coded 2, payment within 30 days of delivery coded 3 , and payment more than 30 days after delivery coded 4 . It is worth noting what was not robustly correlated with payment terms: firm size, CEO ability to speak Chinese, introduction networks, duration of the relationship, views on bribery and perceptions of the business environment. The consistent pattern of the regression coefficients across the import and export estimates suggested pooling (some firms may be separately engaged in both activities) and these pooled regressions are reported in table 9.

Clearly, North Korean counterparties are considered risky (or simply have little negotiating leverage): South Korean exporters received statistically significantly more relaxed payment terms than did North Korean exporters, and transactions that involved a North Korean counterparty (some transactions involved South Korean or third country counterparties operating in North Korea) are associated with more demanding terms than those that did not.

Manufacturing activity was associated with looser settlement terms, while trading was associated with tighter terms.

Activity in KIC was associated with looser settlement terms than the other two modalities, even controlling for the lower incidence of North Korean counterparties in the KIC relative to the other two modalities. Transactions with firms that did not have access to South Korean government support were more demanding, though the precise causality is not clear: it could be that having access to state support makes firms more relaxed about payment terms, or it could be that counterparties, recognizing the state backing, are more relaxed about eventual payment. Intriguingly, transactions involving firms that had access to South Korean dispute resolution were associated with relatively stricter terms.

To get a sense of the relative importance of these correlates, table 10 reports the impact of a one standard deviation change in the independent variables on the dependent variable. The biggest impacts come from the modality variables: activity in the KIC occurs on significantly more forgiving terms than POC or arm's-length transactions. The next most important 
determinant is manufacturing as the activity, followed by having a North Korean counterparty, trade, access to South Korean dispute resolution, and lack of state support.

This pattern — correlation between payment terms and South Korean public policy and the lack of correlation with indicators such as introduction networks, duration of relationship, and bribery, that might be associated with weak institutional environments and recourse to private reputational transacting, as observed in the China survey-suggests through various initiatives the South Korean government has significantly socialized risk.

\section{Conclusion}

Previous research has suggested that North Korea's weak institutional environment imposes risks that limit the magnitude and affect the composition and modalities of cross-border exchange with its largest partner, China (Haggard, Lee, and Noland 2012, Haggard and Noland 2012). Specifically, North Korea's institutional inadequacies encourage Chinese enterprises to employ a variety of hedging strategies, favoring trade over investment for example, and structuring trade in ways that limits their exposure. Yet while private actors may be able to devise informal mechanisms to offset weak public institutions, these private arrangements are likely to be suboptimal and the strengthening of formal institutions could have significant payoffs.

Data derived from a survey of 250 South Korean firms indicate that a different pattern of integration has emerged with North Korea's second largest partner, South Korea, which involves greater direct involvement of South Korean state, greater use of North Korea as an export assembly platform, and a greater incidence of non-North Korean counterparties. These differing modalities of exchange provide an illuminating perspective on the implicit costs of North Korea's weak business environment.

North Korea is risky: Neither Chinese or South Korean firms normally extend credit to their North Korean counterparties. Arm's-length transactions in North Korea, particularly with North Korean counterparties, tend to be conducted on tight financial terms. Yet indicators such as introduction networks, duration of relationship, and bribery, which are evident in China-North Korea interactions, signal recourse to informal contracting and dispute settlement mechanisms, are largely absent. Rather, South Korean public policy has socialized this risk directly via a variety of subsidy, insurance, and preference policies, and indirectly by underwriting the KIC. 
Firms which receive policy support are more likely to enter the market, be profitable, and less likely to quit. They are also more likely to operate out of KIC, and transact on less demanding financial terms. The patterns of correlation suggest a rent-seeking model in which relatively young SMEs in the capitol seek state support to enter the market, and then are reliant on that support to sustain operation once inside North Korea.

This encouragement is not necessarily a bad thing: From a South Korean standpoint, there may be positive social externalities associated with encouraging economic development in North Korea from the standpoint of national reconciliation and eventual reunification. Yet it also means that the level and type of cross-border integration that we observe is very much a product of public policy: Withdraw those supports and it will wither, as South Korean firms are more fully exposed to the unadulterated North Korean policy and infrastructural environment and begin to exhibit the hedging behavior of their Chinese counterparts. Indeed, following a series of provocations by North Korea during 2009-2010, diplomatic relations between North and South Korea soured, and economic integration outside the KIC declined dramatically.

Obversely, from a North Korean perspective, these results underscore the implicit costs of the country's unwillingness or inability to foster modern enabling institutions and provide more robust physical infrastructure. 


\section{Appendix}

A pilot survey was conducted in November 2009 using a survey instrument designed by the authors with the actual interviews conducted by the Millward Brown Media Research. Millward Brown was responsible for securing any local permits and ensuring that the survey was conducted according to the European Society for Opinion and Marketing Research (ESOMAR) rules (http://actrav.itcilo.org/actrav-english/telearn/global/ilo/guide/iccmar.htm). The final survey was conducted during November 2009 and March 2010. The predominant means of conducting the survey was through telephone interviews, though some interviews were conducted face to face. Among the reasons that interviews could not be conducted were refusal by the enterprise to participate prior to or during the interview, inability to establish contact with the enterprise, and the unavailability of the person within the enterprise eligible to respond according to the survey instrument (chairman, manager, etc.). The data - and particularly firm addresses - were subject to post-survey verification by random spot-checking.

Given that there are no known or available registries of all firms doing business with North Korea, the sample of firms doing business with North Korea was of necessity a sample of convenience. The sample was developed using North Korean, South Korean, and Western press accounts, as well as information gathered by Millward Brown in the process of the pilot and interviews with other firms. The sample was drawn from enterprises operating throughout South Korea including the control group of firms not doing business in North Korea.

The design involved a survey of 250 firms, with 200 doing business in North Korea and 50 not doing business in North Korea; in the end, we had 50 responses from firms not doing business in North Korea and 199 firms doing business in North Korea. We defined firms doing business with North Korea to include those that were involved in trading (import, export, or both), investment, processing on commission activities, or that maintained representative offices in North Korea, as well as the 18 firms that had done business and had quit. The control group consisted of 50 firms that had never done business with North Korea.

The survey began with a pilot of 50 firms from throughout South Korea. Although it was understood this was a sample of convenience, enterprises reflecting a broad distribution of size, sector, and provincial location were targeted. Following the successful completion of the pilotwhich did not require fundamental modification of the survey - we were able to transit directly to the full survey and all of the pilot firms were included in the final 249 firms. Once the sample of 199 enterprises operating in North Korea was completed, our aim was to select 50 firms without business relationships with North Korea but with similar qualities with the firms in our treatment group, the firms engaged in business with North Korea (198 firms excluding 1 foreignowned firm). Not all quality variables were available for comparison - we first teased out the firms engaged in manufacturing sector since the majority of our treatment group was in the manufacturing sector. The variables of the two groups were then adjusted so that their categorizations would be comparable with each other. The variables (regions, firm ownership, and firm size) were dummified and we applied the CEM (Coarsened Exact Matching) method in STATA to identify 199 matching firms. We provided a list of 199 firms as lower response rates were expected, and of those, 50 firms were ultimately selected for our control group. 


\section{References}

Anderson, James E., and Douglas Marcouiller. 2002. Insecurity and the Pattern of Trade: An Empirical Investigation. The Review of Economics and Statistics 84, no. 2 (May): 342-52.

Haggard, Stephan, Jennifer Lee, and Marcus Noland. 2012. Integration in the Absence of Institutions: China-North Korea Cross-Border Exchange. Journal of Asian Economics 23, no. 2: $130-45$.

Haggard, Stephan, and Marcus Noland. 2012. Networks, Trust, and Trade: The Microeconomics of China-North Korea Integration. PIIE Working Paper 12-8. Washington: Peterson Institute for International Economics.

Johnson, Simon, John McMillan, and Christopher Woodruff. 1999. Contract Enforcement ain Transition. EBRD Working Paper 45. London: European Bank for Reconstruction and Development.

Johnson, Simon, John McMillan, and Christopher Woodruff. 2002. Courts and relational contracts. Journal of Law, Economics, and Organization 18, no. 1: 221-77.

Kim, Byung-yeon. 2010. Markets, Bribery, and Regime Stability in North Korea. EAI Asia Security Initiative Working Paper no. 4 (April). Seoul: East Asia Institute.

Kim, Sung Chull. 2007. North Korea Under Kim Jong Il: From Consolidation to Systemic Dissonance. Albany: State University of New York Press.

McMillan, John, and Christopher Woodruff. 1999a. Interfirm Relationships and Informal Credit in Vietnam. The Quarterly Journal of Economics 114, no. 4: 1285-1320.

McMillan, John, and Christopher Woodruff. 1999b. Dispute Prevention without Courts in Vietnam. Journal of Law, Economics and Organization 15, no. 3: 637-58.

Moenius, Johannes, and Daniel Berkowitz. 2011. Law, trade, and development. Journal of Development Economics 96: 451-60.

Wei, Shang-Jin. 2000. How Taxing is Corruption on International Investors? The Review of Economics and Statistics 82, no. 1: 1-11. 
Table 1. Product categories of enterprises doing business in North Korea

\begin{tabular}{|c|c|c|c|c|c|c|c|c|c|c|c|c|}
\hline \multirow{3}{*}{ Product Categories } & \multicolumn{2}{|c|}{ Full Sample } & \multicolumn{2}{|c|}{ Non KIC } & \multicolumn{2}{|c|}{ KIC } & \multicolumn{2}{|c|}{ Non Processors } & \multicolumn{2}{|c|}{ Processors } & \multicolumn{2}{|c|}{ Investors } \\
\hline & Exporters & Importers & Exporters & Importers & Export & Importers & Export & porters & Export & Importers & Export & porters \\
\hline & $\%$ & $\%$ & $\%$ & $\%$ & $\%$ & $\%$ & $\%$ & $\%$ & $\%$ & $\%$ & $\%$ & $\%$ \\
\hline Chemicals and chemical products & 4 & 1 & 3 & 1 & 7 & 0 & 4 & 0 & 5 & 2 & 8 & 0 \\
\hline Clothing/textiles & 56 & 35 & 54 & 34 & 61 & 42 & 13 & 20 & 71 & 62 & 56 & 44 \\
\hline $\begin{array}{l}\text { Consumer goods and components } \\
\text { thereof }\end{array}$ & 9 & 7 & 8 & 2 & 11 & 30 & 13 & 3 & 8 & 15 & 4 & 22 \\
\hline Food and fishery products & 6 & 42 & 7 & 50 & 4 & 6 & 9 & 63 & 5 & 6 & 8 & 15 \\
\hline $\begin{array}{l}\text { Industrial/transportation equipment } \\
\text { and intermediates }\end{array}$ & 16 & 4 & 18 & 3 & 11 & 12 & 43 & 3 & 6 & 8 & 12 & 11 \\
\hline Minerals and forestry products & 4 & 4 & 3 & 5 & 7 & 3 & 4 & 6 & 5 & 2 & 8 & 4 \\
\hline Wood products and paper & 4 & 1 & 7 & 1 & 0 & 0 & 13 & 0 & 2 & 2 & 4 & 0 \\
\hline miscellaneous goods & 0 & 5 & 0 & 5 & 0 & 6 & 0 & 6 & 0 & 5 & 0 & 4 \\
\hline
\end{tabular}

Source: Authors' Calculations 


\begin{tabular}{|c|c|c|c|c|c|c|c|c|c|c|c|c|}
\hline \multicolumn{5}{|c|}{ Table 2. Respondent Introduction Networks } & \multicolumn{4}{|c|}{ KIC Only } & \multicolumn{4}{|c|}{ Investors Only } \\
\hline \multirow[b]{2}{*}{ Intro Networks } & \multicolumn{2}{|c|}{ Exporters } & \multicolumn{2}{|c|}{ Importers } & \multicolumn{2}{|c|}{ Exporters } & \multicolumn{2}{|c|}{ Importers } & \multicolumn{2}{|c|}{ Exporters } & \multicolumn{2}{|c|}{ Importers } \\
\hline & $\begin{array}{c}\text { Non NK } \\
\text { Counterpart } \\
\% \text { of } \\
\text { respondents }\end{array}$ & \begin{tabular}{|c|} 
NK \\
Counterparty \\
$\%$ of \\
respondents
\end{tabular} & $\begin{array}{c}\text { Non NK } \\
\text { Counterparty } \\
\% \text { of } \\
\text { respondents }\end{array}$ & $\begin{array}{c}\text { NK } \\
\text { Counterpart } \\
\% \text { of } \\
\text { respondents }\end{array}$ & $\begin{array}{c}\text { Non NK } \\
\text { Counterparty } \\
\% \text { of } \\
\text { respondents }\end{array}$ & $\begin{array}{c}\text { NK } \\
\text { Counterpart } \\
\% \text { of } \\
\text { respondents }\end{array}$ & $\begin{array}{c}\text { Non NK } \\
\text { Counterparty } \\
\% \text { of } \\
\text { respondents }\end{array}$ & $\begin{array}{c}\text { NK } \\
\text { Counterpart } \\
\% \text { of } \\
\text { respondents }\end{array}$ & $\begin{array}{c}\text { Non NK } \\
\text { Counterpart } \\
\% \text { of } \\
\text { respondents }\end{array}$ & $\begin{array}{c}\text { NK } \\
\text { Counterpart } \\
\% \text { of } \\
\text { respondents }\end{array}$ & $\begin{array}{c}\text { Non NK } \\
\text { Counterpart } \\
\% \text { of } \\
\text { respondents }\end{array}$ & \begin{tabular}{|c|} 
NK \\
Counterparty \\
$\%$ of \\
respondents
\end{tabular} \\
\hline $\begin{array}{l}\text { Direct Contact/Knew } \\
\text { Management }\end{array}$ & $0 \%$ & $4 \%$ & $4 \%$ & $2 \%$ & $0 \%$ & $0 \%$ & $3 \%$ & $0 \%$ & $0 \%$ & $0 \%$ & $0 \%$ & $0 \%$ \\
\hline DPRK Public \& Private & $6 \%$ & $13 \%$ & $2 \%$ & $6 \%$ & $4 \%$ & $0 \%$ & $0 \%$ & $0 \%$ & $6 \%$ & $0 \%$ & $0 \%$ & $0 \%$ \\
\hline SK Government & $41 \%$ & $5 \%$ & $40 \%$ & $4 \%$ & $57 \%$ & $0 \%$ & $55 \%$ & $0 \%$ & $61 \%$ & $0 \%$ & $65 \%$ & $0 \%$ \\
\hline Other SK Businesses & $50 \%$ & $47 \%$ & $38 \%$ & $43 \%$ & $39 \%$ & $80 \%$ & $34 \%$ & $75 \%$ & $33 \%$ & $57 \%$ & $25 \%$ & $43 \%$ \\
\hline China Public and Private & $6 \%$ & $24 \%$ & $15 \%$ & $38 \%$ & $0 \%$ & $0 \%$ & $0 \%$ & $0 \%$ & $0 \%$ & $29 \%$ & $0 \%$ & $29 \%$ \\
\hline Other & $3 \%$ & $13 \%$ & $4 \%$ & $10 \%$ & $0 \%$ & $20 \%$ & $7 \%$ & $25 \%$ & $6 \%$ & $14 \%$ & $10 \%$ & $29 \%$ \\
\hline
\end{tabular}

Source: Authors' Calculations 
Table 3. South Korean Support Received

\begin{tabular}{|l|c|cc|c|}
\hline \multicolumn{1}{|c|}{ South Korea Support Received } & Total & Non-KIC & KIC & Quitters \\
\cline { 2 - 5 } & $\begin{array}{c}\text { \% of } \\
\text { respondents }\end{array}$ & $\begin{array}{c}\text { \% of } \\
\text { respondents }\end{array}$ & $\begin{array}{c}\text { \% of } \\
\text { respondents }\end{array}$ & $\begin{array}{c}\% \text { of } \\
\text { respondents }\end{array}$ \\
\hline Special tariff reduction/Preferential & 23 & 21 & 33 & 6 \\
trade treatment received & 8 & 2 & 33 & 0 \\
Special financing convenience received & 4 & 1 & 18 & 0 \\
Ex/Im insurance received & 3 & 0 & 15 & 0 \\
Investment guarantee received & 70 & 76 & 39 & 94 \\
No government support received & \multicolumn{2}{|l}{} \\
\hline
\end{tabular}

Source: Authors' Calculations 
Table 4. Entry Regressions

Binary Model (1=Entry Into Business in DPRK, $0=$ No Entry Into DPRK)

Age of Firm

\begin{tabular}{|c|c|c|c|}
\hline (4.1) & (4.2) & (4.3) & (4.4) \\
\hline-0.002 & $-0.003^{*}$ & -0.002 & \\
\hline (0.002) & $(0.002)$ & $(0.002)$ & \\
\hline $0.098^{\star \star}$ & $0.123^{\star \star \star}$ & $0.097^{\star \star}$ & $0.101^{\star * *}$ \\
\hline$(0.040)$ & $(0.041)$ & $(0.040)$ & (0.039) \\
\hline $0.121^{* * *}$ & $0.137^{\star * *}$ & $0.122^{\star * \star}$ & $0.133^{\star * *}$ \\
\hline$(0.044)$ & $(0.047)$ & $(0.044)$ & $(0.043)$ \\
\hline $0.081^{*}$ & $0.092^{\star \star}$ & $0.081^{*}$ & $0.091^{* \star}$ \\
\hline (0.043) & $(0.046)$ & $(0.042)$ & $(0.043)$ \\
\hline $0.099^{* * *}$ & $0.111^{* * *}$ & $0.099^{\star * *}$ & $0.097^{* * *}$ \\
\hline$(0.034)$ & $(0.040)$ & $(0.034)$ & $(0.035)$ \\
\hline$-0.244^{* * *}$ & & $-0.257^{* * *}$ & $-0.263^{\star * *}$ \\
\hline \multirow[t]{3}{*}{$(0.045)$} & & $(0.076)$ & $(0.075)$ \\
\hline & $0.186^{\star * *}$ & -0.024 & -0.033 \\
\hline & $(0.039)$ & $(0.115)$ & $(0.117)$ \\
\hline
\end{tabular}

\section{Observations}

II

chi2

$\begin{array}{llll}246 & 246 & 246 & 248\end{array}$

$\begin{array}{llll}-90.43 & -97.70 & -90.41 & -91.75\end{array}$

r2_p

67.54

53.00

67.59

65.81

Standard errors in parentheses

$0.272 \quad 0.213$

0.272

0.264

${ }^{* \star *} p<0.01,{ }^{* *} p<0.05,{ }^{*} p<0.1$

Source: Authors' Calculations 
Table 5. Modality Regressions

CEO speaks Chinese

(5.1) (5.2)

$-0.303$

$(0.446)$

All non-manufacturing enterprises

$-3.361^{* * *}-3.400^{* * *}$

$(0.480) \quad(0.480)$

$1.633^{\star \star} \quad 1.647^{\star \star}$

Special financing convenience received

(0.731) (0.727)

Received funding from state affiliated sources $1.827^{\star *}$

$1.867^{* *}$

$(0.878) \quad(0.872)$

Received funding from commercial banks

$1.128^{\star *} \quad 1.179^{\star \star \star}$

(0.443) (0.437)

NK tax too high

getting easier to do business in NK

Ban on cell phones- hurt business

At least one NK counterparty

$-1.352^{\star \star *}-1.376^{\star \star \star}$

(0.410) (0.409)

cut1

Constant

$-1.010^{* *} \quad-0.914^{*}$

(0.515) (0.493)

cut2

Constant

$0.963^{*} \quad 1.045^{\text {** }}$

(0.519) (0.504)

Observations

$195 \quad 196$

II

$-109.3 \quad-109.6$

chi2

$135.2 \quad 135.5$

r2 $p$

0.382

0.382

Standard errors in parentheses

${ }^{* * *} p<0.01,{ }^{* *} p<0.05,{ }^{*} p<0.1$

${ }^{*}$ Categorical Model ( $1=$ Arm's Length Export/Import,

2= Non KIC Process on Commission, 3=KIC Enterprises)

Source: Authors' calculations 
Table 6. Exit Regressions

Small and Medium Firms: Sales $<=150$ million Won Binary Model (1=Quit, $0=$ Remained)

CEO speaks Chinese

\begin{tabular}{cccc}
$\mathbf{( 6 . 1 )}$ & $\mathbf{( 6 . 2 )}$ & $\mathbf{( 6 . 3 )}$ & $\mathbf{( 6 . 4 )}$ \\
\hline 0.038 & & 0.036 & \\
$(0.029)$ & & $(0.032)$ & \\
$-0.071^{\star \star \star}$ & $-0.075^{\star \star \star}$ & $-0.078^{\star \star \star}$ & $-0.079^{\star \star \star}$ \\
$(0.026)$ & $(0.027)$ & $(0.029)$ & $(0.029)$ \\
$-0.141^{\star \star}$ & $-0.143^{\star \star}$ & & \\
$(0.059)$ & $(0.060)$ & & \\
0.045 & $0.055^{\star}$ & $0.078^{\star \star *}$ & $0.086^{\star \star \star}$ \\
$(0.029)$ & $(0.029)$ & $(0.030)$ & $(0.030)$ \\
192 & 192 & 198 & 198 \\
-44.94 & -45.88 & -51.12 & -51.79 \\
24.99 & 23.11 & 13.73 & 12.39 \\
0.218 & 0.201 & 0.118 & 0.107 \\
\hline
\end{tabular}

Able to make a profit in DPRK

No South Korean Government Support

Observations

II

chi2

r2 p

Standard errors in parentheses

${ }^{* * *} p<0.01,{ }^{* *} p<0.05,{ }^{*} p<0.1$

Source: Authors' Calculations 
Table 7. Exporter Settlement Terms

\begin{tabular}{|c|c|c|c|c|c|c|c|}
\hline \multirow{3}{*}{$\begin{array}{l}\text { Exmodal: Most Common } \\
\text { Method of Payment }\end{array}$} & \multirow{2}{*}{$\begin{array}{c}\text { All Exporters } \\
\text { All } \\
\text { Counterparties }\end{array}$} & \multicolumn{2}{|c|}{ Pure Exporters } & \multicolumn{2}{|c|}{ Process Exporters } & \multicolumn{2}{|c|}{ KIC } \\
\hline & & $\begin{array}{c}\text { Non NK } \\
\text { Counterparty }\end{array}$ & $\begin{array}{c}\text { NK } \\
\text { Counterparty } \\
\end{array}$ & $\begin{array}{c}\text { Non NK } \\
\text { Counterparty }\end{array}$ & $\begin{array}{c}\text { NK } \\
\text { Counterparty }\end{array}$ & $\begin{array}{c}\text { Non NK } \\
\text { Counterparty }\end{array}$ & $\begin{array}{c}\text { NK } \\
\text { Counterparty }\end{array}$ \\
\hline & $\%$ & $\%$ & $\%$ & $\%$ & $\%$ & $\%$ & $\%$ \\
\hline Time of order placement & $11 \%$ & $0 \%$ & $33 \%$ & $0 \%$ & $10 \%$ & $0 \%$ & $0 \%$ \\
\hline Time of delivery & $23 \%$ & $38 \%$ & $33 \%$ & $0 \%$ & $26 \%$ & $0 \%$ & $0 \%$ \\
\hline Within 1 to 30 days & $27 \%$ & $25 \%$ & $27 \%$ & $19 \%$ & $32 \%$ & $7 \%$ & $0 \%$ \\
\hline After 30 days & $39 \%$ & $38 \%$ & $7 \%$ & $81 \%$ & $32 \%$ & $93 \%$ & $100 \%$ \\
\hline Total & $100 \%$ & $100 \%$ & $100 \%$ & $100 \%$ & $100 \%$ & $100 \%$ & $100 \%$ \\
\hline
\end{tabular}

Source: Authors' Calculations 
Table 8. Importer Settlement Terms

\begin{tabular}{|l|c|c|c|c|c|c|c|}
\hline \multirow{3}{*}{$\begin{array}{c}\text { Immodal: Most Common } \\
\text { Method of Payment }\end{array}$} & All Importers & \multicolumn{2}{|c|}{ Pure Importers } & \multicolumn{2}{|c|}{ Process Importers } & \multicolumn{2}{c|}{ KIC } \\
\cline { 2 - 8 } & $\begin{array}{c}\text { All } \\
\text { Counterparties }\end{array}$ & $\begin{array}{c}\text { Non NK } \\
\text { Counterparty }\end{array}$ & $\begin{array}{c}\text { NK } \\
\text { Counterparty }\end{array}$ & $\begin{array}{c}\text { Non NK } \\
\text { Counterparty }\end{array}$ & $\begin{array}{c}\text { NK } \\
\text { Counterparty }\end{array}$ & $\begin{array}{c}\text { Non NK } \\
\text { Counterparty }\end{array}$ & $\begin{array}{c}\text { NK } \\
\text { Counterparty }\end{array}$ \\
\cline { 2 - 8 } & $\%$ & $\%$ & $\%$ & $\%$ & $\%$ & $\%$ & $\%$ \\
\hline Time of order placement & $18 \%$ & $10 \%$ & $29 \%$ & $0 \%$ & $5 \%$ & $0 \%$ & $0 \%$ \\
Time of delivery & $36 \%$ & $30 \%$ & $48 \%$ & $0 \%$ & $29 \%$ & $0 \%$ & $0 \%$ \\
Within 1 to 30 days & $31 \%$ & $50 \%$ & $23 \%$ & $36 \%$ & $40 \%$ & $42 \%$ & $0 \%$ \\
After 30 days & $15 \%$ & $10 \%$ & $1 \%$ & $64 \%$ & $26 \%$ & $58 \%$ & $100 \%$ \\
\hline Total & $100 \%$ & $100 \%$ & $100 \%$ & $100 \%$ & $100 \%$ & $100 \%$ & $100 \%$ \\
\hline
\end{tabular}

Source: Authors' Calculations 
Table 9. Settlement Terms Regressions

\begin{tabular}{|c|c|c|}
\hline & $(9.1)$ & $(9.2)$ \\
\hline Exporters: those who answered export payment term questic & $\begin{array}{l}0.596^{*} \\
(0.312)\end{array}$ & $\begin{array}{l}0.596^{*} \\
(0.312)\end{array}$ \\
\hline Have a factory in Kaesong Industrial Complex & & $\begin{array}{c}2.912^{* * *} \\
(0.573)\end{array}$ \\
\hline Arm's length exporter or importer, Non-poc, non-kic & $\begin{array}{c}-2.912^{* * *} \\
(0.573)\end{array}$ & \\
\hline POC firm operating outside of KIC & $\begin{array}{c}-2.608^{* * *} \\
(0.553)\end{array}$ & $\begin{array}{c}0.304 \\
(0.374)\end{array}$ \\
\hline At least one NK counterparty & $\begin{array}{l}-0.758^{*} \\
(0.388)\end{array}$ & $\begin{array}{l}-0.758^{*} \\
(0.388)\end{array}$ \\
\hline Did not receive any government support & $\begin{array}{l}-0.503^{*} \\
(0.300)\end{array}$ & $\begin{array}{l}-0.503^{*} \\
(0.300)\end{array}$ \\
\hline SK public or private dispute resolution & $\begin{array}{l}-0.840^{*} \\
(0.451)\end{array}$ & $\begin{array}{c}-0.840^{*} \\
(0.451)\end{array}$ \\
\hline Prinicpal activity of enterprise is manufacturing & $\begin{array}{c}1.442^{\star * *} \\
(0.446)\end{array}$ & $\begin{array}{c}1.442^{* * *} \\
(0.446)\end{array}$ \\
\hline Principal activity of enterprise is trade & $\begin{array}{c}-0.784^{* *} \\
(0.377)\end{array}$ & $\begin{array}{c}-0.784^{* *} \\
(0.377)\end{array}$ \\
\hline cut1 & & \\
\hline Constant & $\begin{array}{c}-5.337^{* * *} \\
(0.740)\end{array}$ & $\begin{array}{c}-2.425^{\star * *} \\
(0.550)\end{array}$ \\
\hline cut2 & & \\
\hline Constant & $\begin{array}{c}-2.991^{\star * \star} \\
(0.720)\end{array}$ & $\begin{array}{l}-0.080 \\
(0.523)\end{array}$ \\
\hline cut3 & & \\
\hline Constant & $\begin{array}{l}-0.424 \\
(0.682)\end{array}$ & $\begin{array}{c}2.487^{\star \star \star} \\
(0.563)\end{array}$ \\
\hline Observations & 248 & 248 \\
\hline II & -242.6 & -242.6 \\
\hline chi2 & 185.4 & 185.4 \\
\hline r2_p & 0.277 & 0.277 \\
\hline
\end{tabular}

Standard errors in parentheses

${ }^{* * *} p<0.01,{ }^{* *} p<0.05,{ }^{*} p<0.1$

*Dependent variable takes on values 1-4. 1=Payment at time of order, 2=Payment upon delivery, $3=$ Payment within 30 days of deliver, $4=$ Payment after 30 days of delivery

Source: Authors' Calculations 


\section{Table 10. Magnitude of impact on settlement terms of a one standard deviation change in the}

explanatory variable

estimated from (9.1) estimated from (9.2)

Exporters: those who answered export payment term questions

0.25

0.25

Have a factory in Kaesong Industrial Complex

- 1.15

Arm's length exporter or importer, Non-poc, non-kic

$-1.45$

POC firm operating outside of KIC

$-1.08$

0.13

At least one NK counterparty

$-0.34$

$-0.34$

Did not receive any government support

$-0.23$

$-0.23$

SK public or private dispute resolution

$-0.29$

$-0.29$

Prinicpal activity of enterprise is manufacturing

0.71

0.71

Principal activity of enterprise is trade

$-0.34$

$-0.34$

Note: regression coefficients are drawn from an ordered logistic model and therefore do not have easilly interpretable meaning. The results above indicate magnitude but not a specific change in the dependant variable

Source: Authors' Calculations. 
Figure 1. Composition of 199 Enterprises Doing Business in North Korea

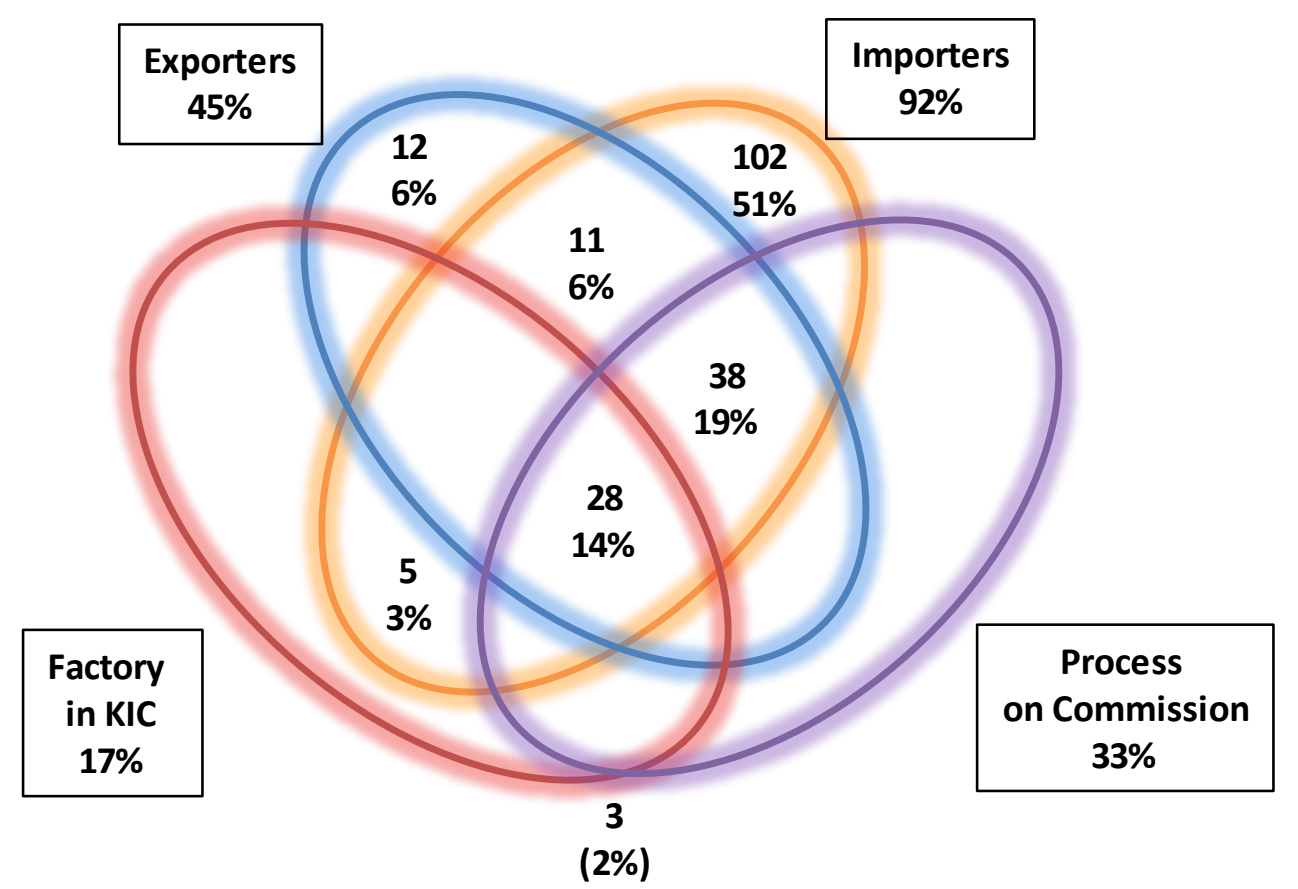

Source: Authors' Calculations 


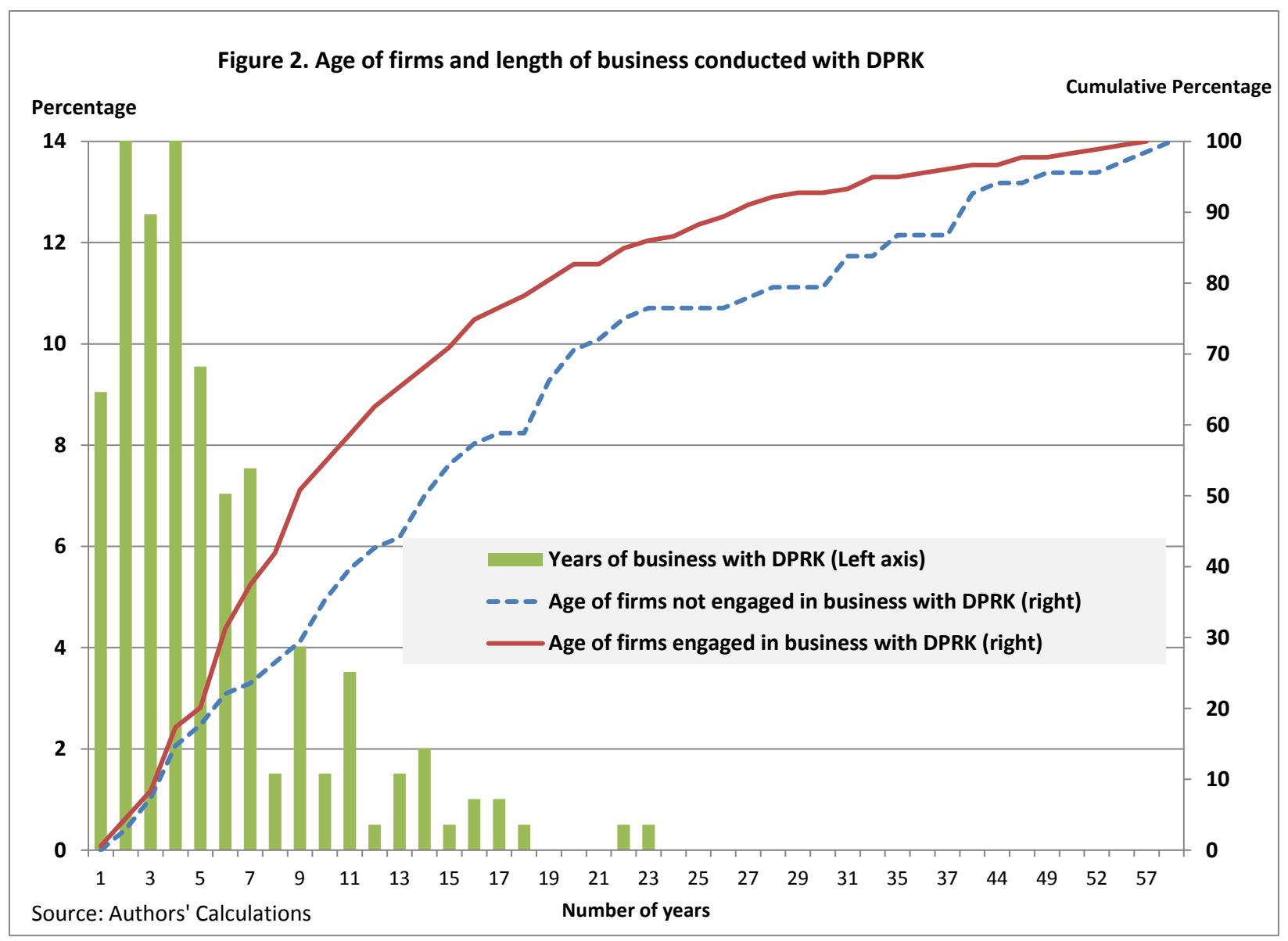




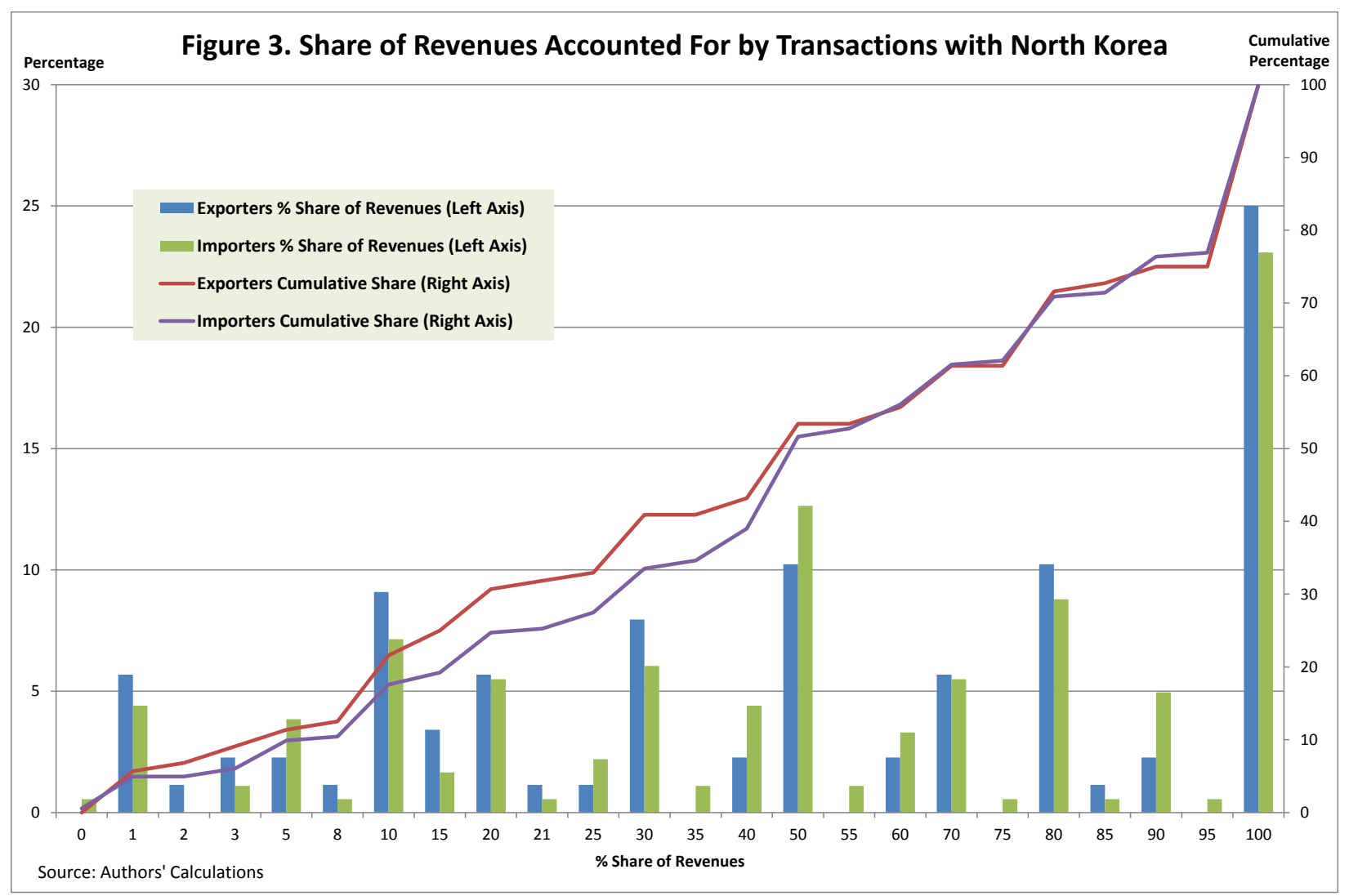




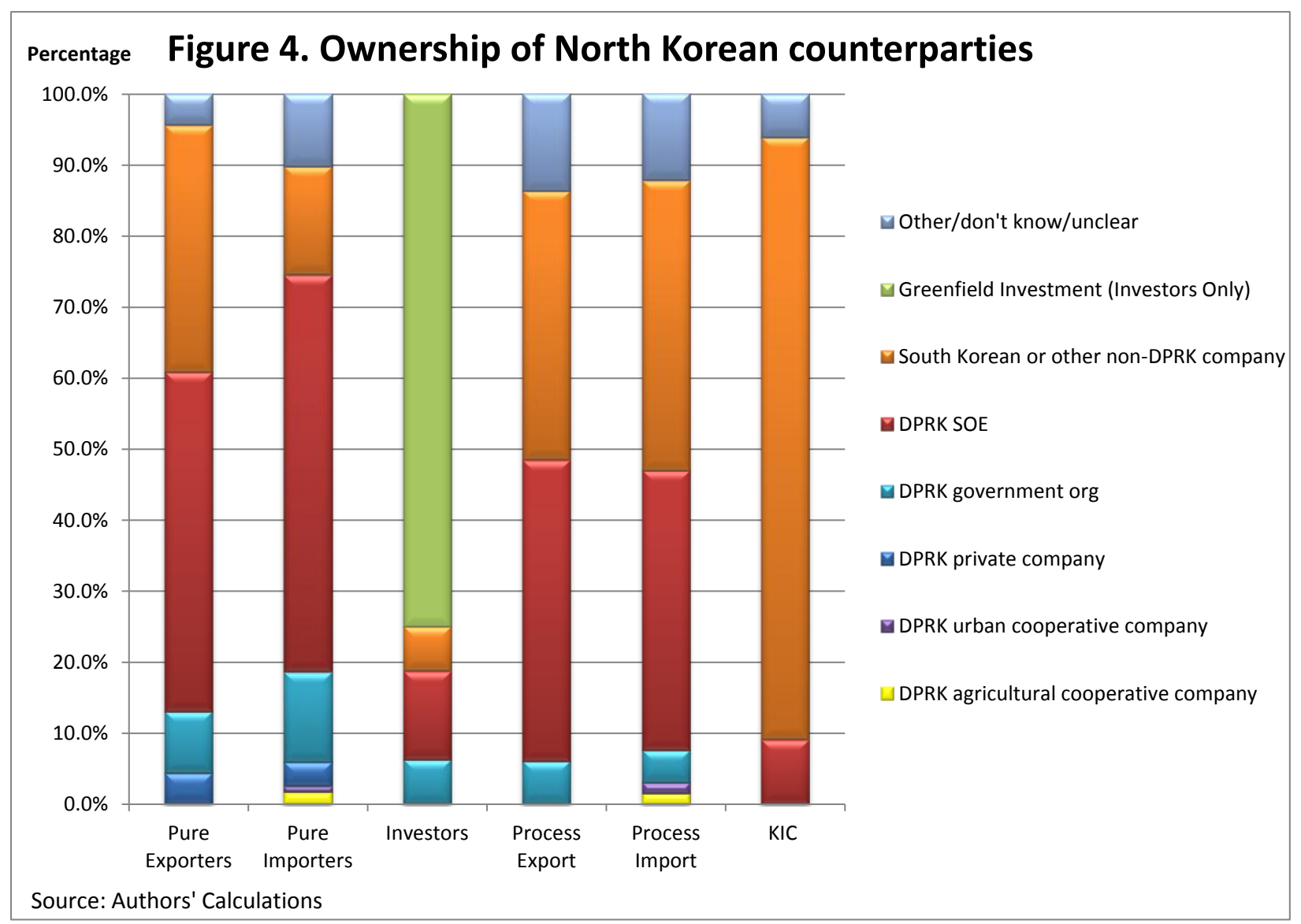




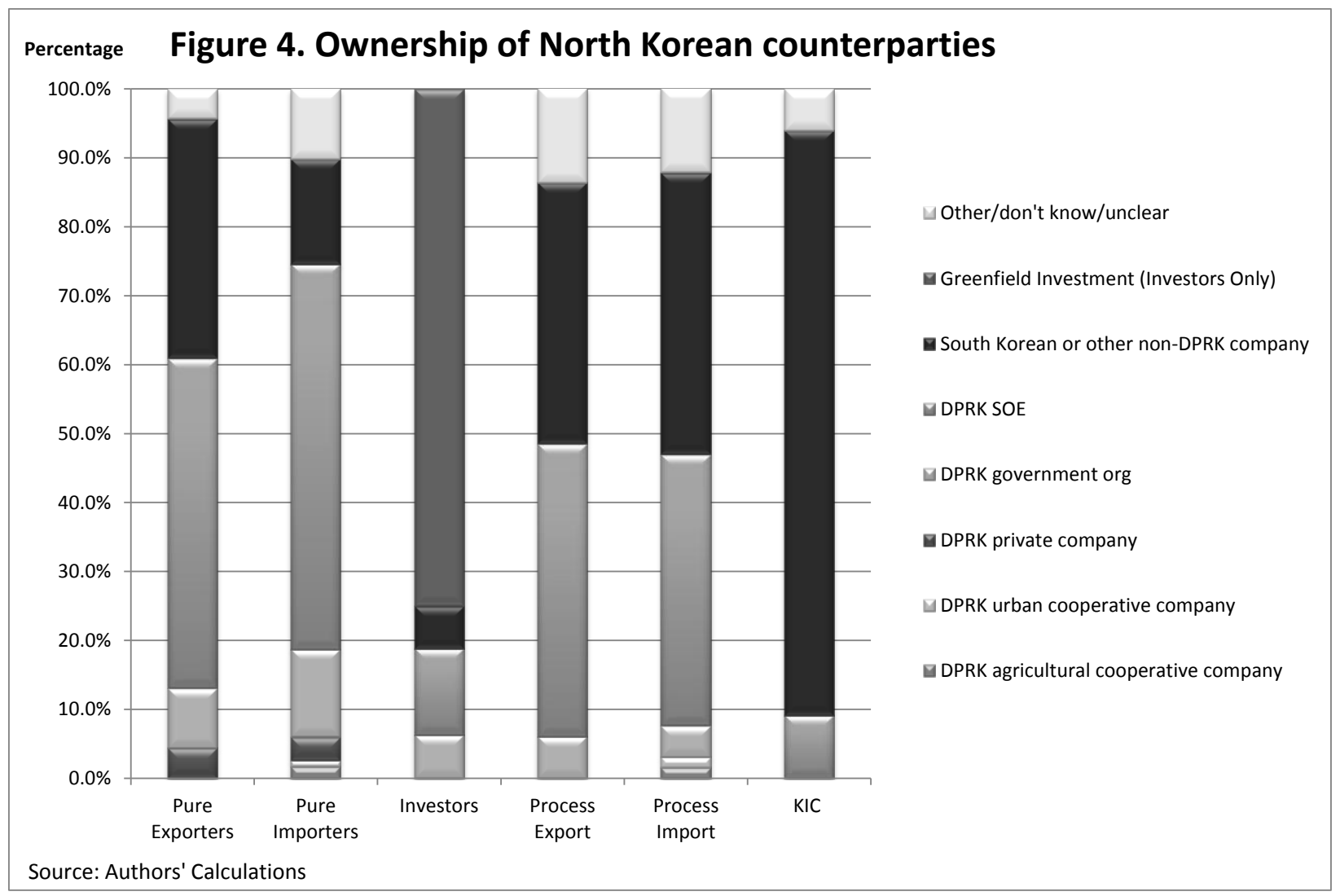




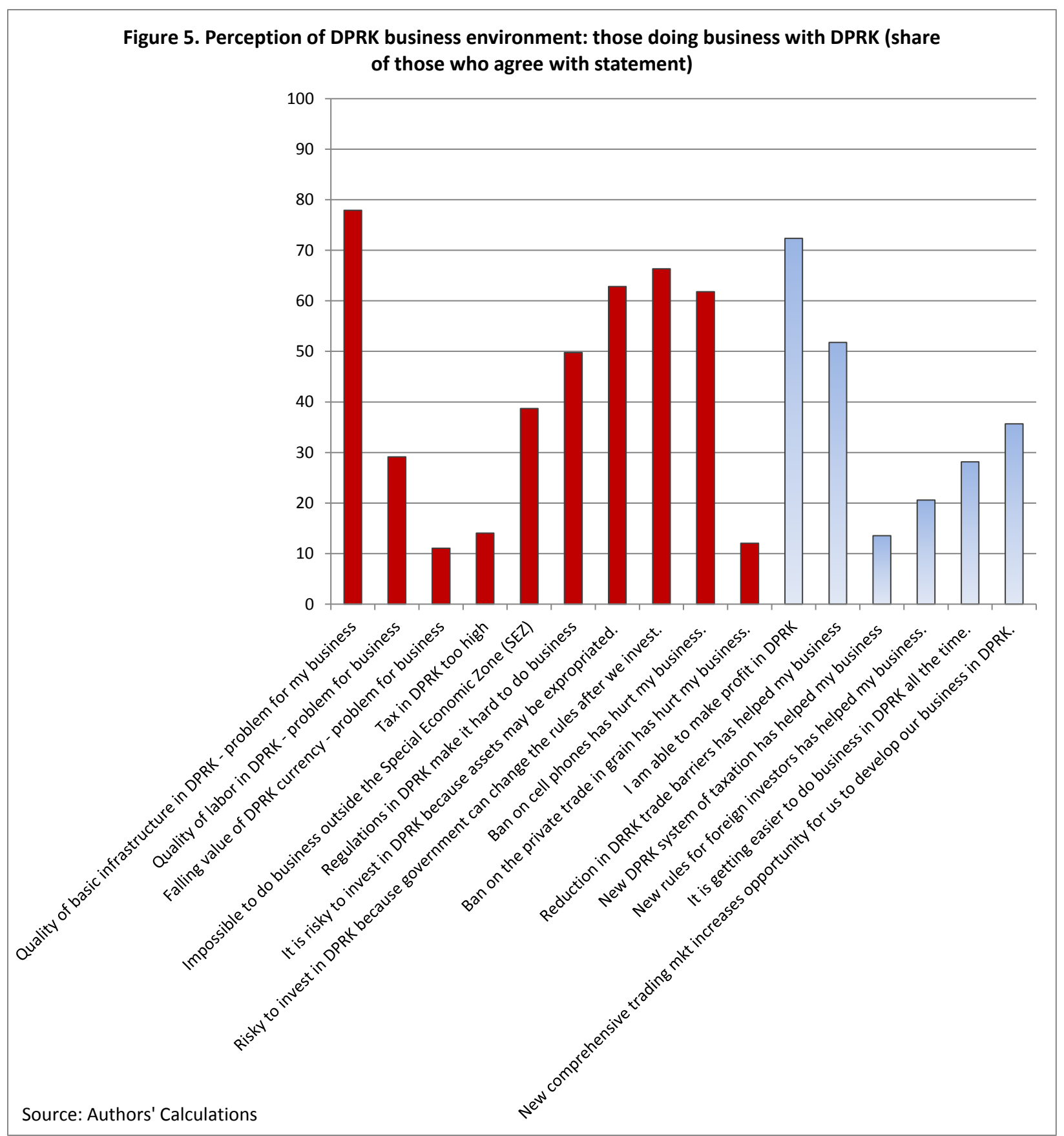




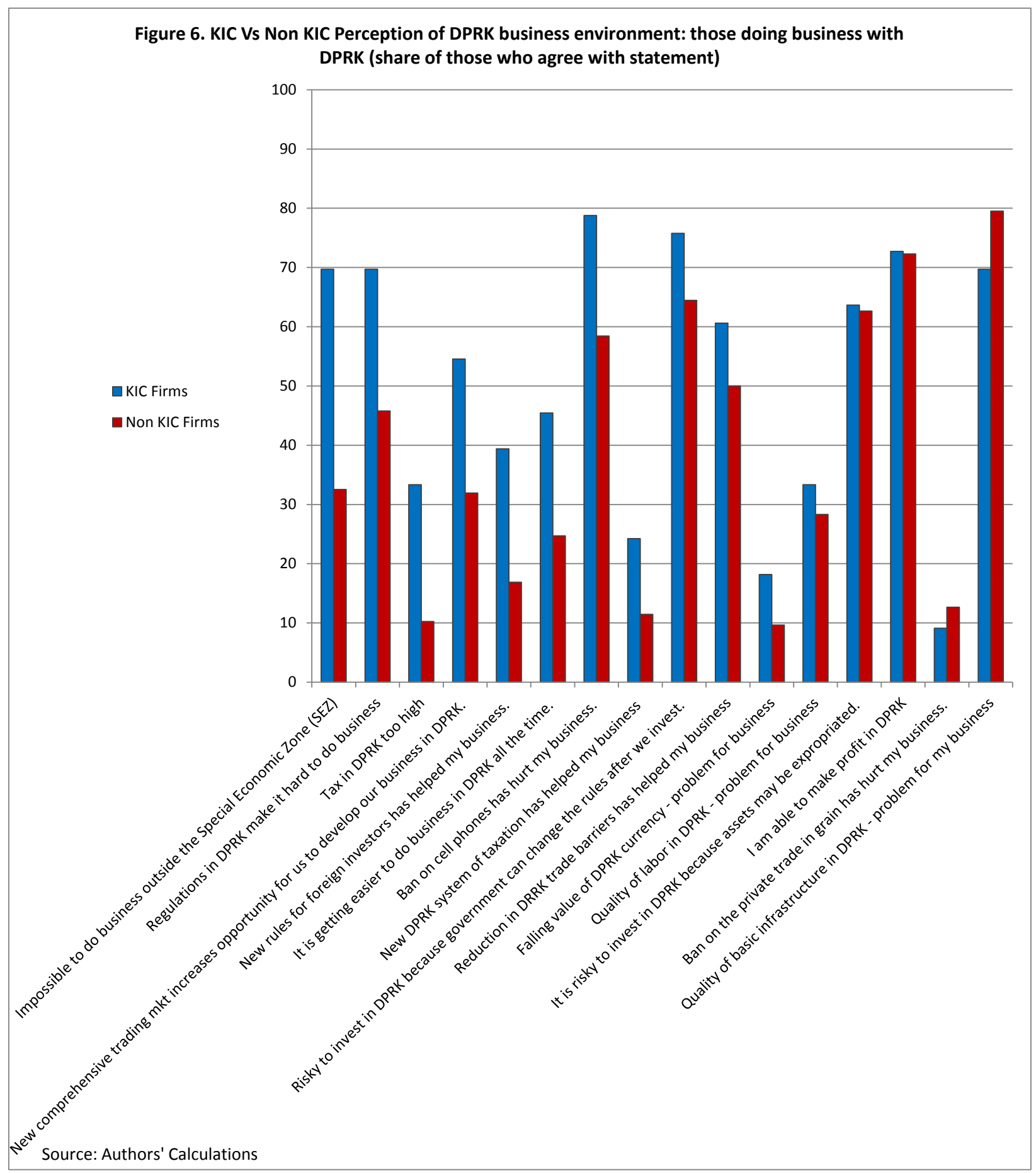

